\title{
СЕКУРИТИЗАЦИЈА (У ВРЕМЕ) ПАНДЕМИЈЕ: ИЛОКУЦИОНА КАКОФОНИЈА И ВИРАЛНИ ОТПОР ВАНРЕДНИМ МЕРАМА СУЗБИЈАҢА КОВИДА 19 У РЕПУБЛИЦИ СРБИЈИ
}

\author{
доц. др Владимир Ајзенхамер ${ }^{1}$
}

Апстракт: Аутор се у раду бави питањем секуритизације пандемије вируса ковид 19 у Републици Србији, усмеравајући своју пажњу на дискурс отпора ванредним мерама који се у делу грађанства јавио непосредно након њиховог увођења. Овај дискурс је превасходно заступљен у online заједници и захваљујући својству виралности веома се брзо раширио друштвеним медијима и мрежама. Позив на супротстављање уведеним противпандемијским мерама има за своју последицу слабљење учинковитости државе као секуритизујућег актера и умањење подршке безбедносној политици дугорочне имплементације друштвених рестрикција намењених сузбијању заразе. Циљ рада је да путем теоријске елаборације званичног секуритизујућег дискурса и дискурса његових опонената укаже на разлоге који су довели до губитка поверења шире јавности у ауторитет политичких и стручњачких елита као легитимних носилаца борбе против вируса. Ауторова основна теза је да се у арени здравствене безбедности јавило више претендената на улогу секуритизујућег актера, чиме су измењена важећа правила специјализованих дискурзивних поредака, превасходно она која се тичу њихове контроле и саморегулације. Како би поткрепио ову тезу, аутор у традиционални образац секуритизације уводи два иновативна теоријска концепта - принцип згрушавања дискурса и илокуциону какофонију.

Кључне речи: ковид 19, дискурс, секуритизација, секуритизујући актер, згрушавање дискурса, илокуциона какофонија, ванредне мере, друштвене мреже, отпор ванредним мерама, антивакциони покрет.

1 Универзитет у Београду, Факултет безбедности; e-mail: ajzenhamer@fb.bg.ac.rs . 


\section{Увод}

Рад који је пред читаоцима представља кратак теоријски екскурс на тему односа државе и грађана Републике Србије према глобалној пандемији вируса ковид 19. Истраживачки фокус биће стављен на питање немогућности државе, као легитимног секуритизатора, да обезбеди дугорочну подршку спровођењу ванредних здравствених и друштвених мера намењених превенцији и сузбијању ширења заразе. Отуда се овај рад не бави питањем (не)учинковитости предузетих мера, већ је његова пажња усмерена искључиво ка дискурзивној димензији пандемијске кризе. Наш циљ је да путем кратке елаборације званичног секуритизујућег дискурса, са једне стране, и дискурса његових опонената, са друге стране, покушамо да укажемо на разлоге који су довели до губитка поверења шире јавности у ауторитет политичких и стручњачких елита које су на себе преузеле борбу против вируса. Наиме, у Србији је након фазе иницијалног успеха секуритизације пандемије која се огледала у брзој имплементацији ванредних мера и увођењу ванредног стања (почетком марта 2020) дошло до наглог пораста сумње у исправност и сврсисходност поменутих мера. Након укидања ванредног стања и ублажавања рестриктивних мера ово пропитивање прерасло је у масовни одијум грађана према могућности поновног увођења социјалних рестрикција, што је почетком јула месеца довело и до грађанских протеста и уличних немира.

Наша основна теза је да је до компромитовања далекосежне секуритизације пандемије ковид 19 дошло услед неадекватно спроведеног секуритизујућег потеза, приликом чије примене није вођено рачуна о тзв. граматици безбедности као једном од кључних предуслова успеха. Овај пропуст, начињен у најважнијем сегменту секуритизујућег ланца говорни актер - говорни чин - публика, код потоње је изазвао ефекат супротан жељеном, те су мере заштите од стране грађана убрзо све више перципиране као наметнуте и присилне. Ово неповерење додатно је појачано екстерним условима у којима се одвијао покушај секуритизације, а који је подразумевао изразито асертивну и агресивну делатност српских антивакцинаша (тзв. антиваксера), који су се путем дигиталних друштвених медија и мрежа укључили у безбедносни дискурс и иницирали сопствени покушај секуритизације. Тако се у арени здравствене безбедности јавило више претендента на улогу секуритизујућег актера, чиме су измењена важећа правила специјализованих дискурзивних поредака, превасходно она која се тичу њихове контроле и саморегулације.

Како бисмо боље разумели суштину ове промене, која уједно представља и кључ за разумевање социјалнополитичких импликација пандемије ковида 19 по српско друштво, у традиционални образац секуритизације увешћемо два нова принципа, која ћемо назвати згрушавање дискурса и илокуциона какофонија. Они ће у наставку рада истовремено бити третирани и као теоријски концепт неопходан за разумевање дисхармоничног вишегласја у оквиру безбедносног дискурса о пандемији, али и као отежавајући принципи/услови који опструирају успешну реализацију вертикалне, тј. државоцентричне секуритизације, а који уједно 
погодују хоризонталној псеудосекуритизацији, коју путем интернета врше, „неконвенционални“ претенденти на улогу секуритизатора.

У првом делу рада позабавићемо се основним претпоставкама теорије секуритизације, у чијој основи лежи идеја о безбедности као говорном чину. Након тога покушаћемо да путем укрштања Фукоовог (Michel Foucault) принципа проређивања говорног субјекта и Кастелсовог (Manuel Castells) концепта масовне самокомуникације објаснимо промене у оквиру дискурса о безбедности, до којих је дошло услед нагле експанзије дигиталних технологија и виртуелног умрежавања појединаца посредством друштвених медија и мрежа. У овом поглављу прецизније ћемо одредити концепте згрушавања говорног субјекта (који ћемо позиционирати као својеврсну антитезу Фуковом правилу проређивања дискурса), као и феномен илокуционе какофоније (који ћемо посматрати као главну препреку успешној секуритизацији пандемије ковида 19). Напослетку, поменути концепти биће примењени на случај Републике Србије и расветљавање узрока који су довели до грађанског отпора секуритизацији и ванредним мерама сузбијања пандемије.

\section{БЕЗБЕДНОСТ КАО ГОВОРНИ ЧИН И СЕКУРИТИЗУЈУЋИ ДИСКУРС}

У Фукоовој филозофији знања дискурс представља оквир и спољну границу исказа, мада је прецизно одређење овог појма изостало, а његова примена варира у зависности од аналитичког фокуса. За Фукоа је дискурс час „опште подручје свих исказа, час група исказа која се може индивидуализовати, час правилима уређена делатност која се односи на одређен број исказа“.2 Синтетишући поменута значења, Сара Милс (Sara Mills) дискурс одређује као регулисану групу исказа која се комбинује са другима на предвидљиве начине и којим се „регулише скуп правила која воде у дистрибуирање и кружење извесних изјава и исказа“.3 Но између језика и дискурса, упркос чињеници да се исказ у оба случаја јавља као њихова конститутивна јединица, нипошто не сме бити стављен знак једнакости. Дискурс није реалност исказана говорним чином или текстом, односно просто превођење објективно спознајне стварности у језик. Њега треба сагледати као „систем који структурира начин на који перципирамо реалност“. ${ }^{4}$ Дакле, није реч тек о језичком отелотворењу или манифестацији реалности, па чак ни о њеној семантичкој рефлексији. Суштина дискурса лежи, како то примећује Стјуарт Хол (Stuart Hall), у производњи знања, тј. у репрезентацији реалности одабиром

\footnotetext{
2 Мишел Фуко, Археологија знања, Плато, Издавачка књижница Зорана Стојановића, Београд/Нови Сад, 1988, стр. 88.

3 Сара Милс, „Шта је дискурс?“, У: Мишел Фуко, Поредак дискурса, Карпос, Лозница, 2019, стр. 49.

4 Сара Милс, ибид, стр. 51.
} 
одређеног скупа исказа који нам нуди језик за говор о одређеној теми. ${ }^{5}$ Како „свет и материјалне објекте можемо искусити и о њима мислити у целини само путем дискурса и структура што се намећу нашем мишљењу“,6 поменуто знање није одраз објективне стварности, већ је реч о једној од мноштва њених могућих интерпретација, добијеној на основу значења пренесеног одређеним комбинацијама исказа. Стога Изабела (Isabela Fairclough) и Норман Феркалф (Norman Fairclough) дискурс виде као међусобну усклађеност репрезентација света, тј. његових одређених аспеката, с једне, и позиција или перспектива различитих група друштвених актера, са друге стране.7 Једноставно речено, различити друштвени актери виде свет на различите начине и у складу са тим виђењем креирају различите дискурсе.

Тако одређен, феномен дискурса не подлеже конвенционалној дистинкцији између делања и мишљења, односно језика и праксе. Наиме, иако се дискурс превасходно тиче производње знања кроз језик, „он се сам производи уз помоћ 'дискурзивне праксе' - праксе произвођења значења. Пошто све друштвене праксе укључују значење, све праксе имају дискурзивни аспект. На тај начин дискурс улази у све друштвене праксе и на све њих утиче“.8 Сходно томе, дискурс можемо означити као тачку сусрета језика и праксе, или као синтетишућу силу која обе категорије ставља у погон зарад поменутог циља - продуковања представа о свету који нас окружује. Ова синтеза произилази из чињенице да друштвене структуре, праксе и догађаји имају делимично семиотички карактер, 9 док се, са друге стране, у самом језику крије делатни, тј. перформативни потенцијал. ${ }^{10}$ Управо на трагу потоњег - перформативне моћи језика, изведена је и теза о безбедности као говорном чину, која ће постати стожерна идеја теорије секуритизације.

Концепт секуритизације осмишљен је од стране теоретичара тзв. Копенхашке школе безбедности који су приступ овом феномену установили као својеврсну дисциплинарну парафразу филозофије говорног чина Остина (John L. Austin) и Серла (John R. Searle). Инспирисан Остиновим концептом перформативне изјаве (performative utterance) Уле Вејевер је безбедност поистоветио са илокуционим говорним чином који поседује моћ да самим изговарањем (utterance) неко друштвено питање трансформише у безбедносно питање. За Вејвера изговарање безбедности јесте per se безбедност, јер је „изговарање само по себи чин. Рећи нешто значи учинити нешто (као у клађењу, давању обећања, именовању брода).

5 Стјуарт Хол, Запад и остатак света: Дискурс и моћ, Карпос, Лозница, 2019, стр. 32-33.

6 Сара Милс, ор. cit., стр. 52.

7 Isabela Fairclough, Norman Fairclough, Political Discourse Analysis: A method for advanced students, Routledge,

London/New York, 2012, p. 82.

${ }^{8}$ Стјуарт Хол, оp. cit., стр. 32-33.

${ }^{9}$ Isabela Fairclough, Norman Fairclough, op.cit, p. 82.

10 John L. Austin, How to Do Things With Words, Oxford University Press, London, 1962. 
Изговарајући „безбедност“, представник државе премешта одређени догађај у одређену област, и тамо захтева специјално право на употребу средстава потребних за његово заустављање“.11 Овај процес је у потпуности дискурзивног карактера, те као такав није везан за истинитост изнете тврдње, већ првенствено зависи од намере говорног актера, тј. секуритизатора да одређено питање представи као безбедносно.

Доследно идеји да језик претходи реалности, Вејвер сматра да реалност (претње) не производи безбедност, већ да је она производ самог исказа о претњи. Дакле, језик не само да претходи безбедности, већ је он и ствара. Отуда је за Beјвера (Ole Waever) безбедност самореферишућа пракса одређена интенцијом и перцепцијом онога ко о њој говори. Дакле, баш као што за Хола дискурс није рефлексија стварности, тако и за Вејвера безбедност није одраз стварних претњи. Овде је неопходно напоменути да се говорни чин ипак битно разликује од перцепције. Перцепција претње тиче се нечега што долази из окружења, док је говорни чин самореферишућа пракса која утиче на окружење. ${ }^{12}$ Могло би се закључити да је перцепција по свом карактеру реактивна, јер представља последицу, тј. реакцију на екстерни input, док је говорни чин проактиван и делује као перформативни исказ којим се претња конституише. Дистинкција на мишљење и дело, која је прогнана из теоретисања о дискурсу, овде је поново на снази. Одређена перцепција може и не мора прећи у делање, док говорни чин сам по себи јесте делање - рећи значи учинити.

Треба имати на уму да процес секуритизације не почива на било којој врсти изјаве, већ да она, како смо претходно истакли, по своме карактеру мора бити илокуциони исказ. Наиме, према Остину свака реченица може у себи садржати три врсте поступка - локуцију (locutionary act), илокуцију (illocutionary act) и перлокуцију (perlocutionary act), а њихова комбинација одредиће природу ситуације изазване говорним чином. Локуција подразумева сам чин изговарања реченице, односно употребу говора да би се исказао одређени садржај, смисао или референца. Илокуција је артикулација локуције у правцу одређене намере или захтева за извршењем одређене радње. Она се у великој мери може поистоветити са самим концептом говорног чина, јер јој је својство перформативности иманентно. Напослетку, перлокуција подразумева успешно извршење поменуте намере или захтева, и реферише на ефекте које тај чин изазива код циљане публике - осећања, мисли, намере или активности. ${ }^{13}$ Секуритизација стога није

11 Ole Waever, „Securitisation and Desecuritisation“, in Ronnie D. Lipschutz (ed.), On secuirty, Columbia University Press, New York, 1995, p. 55.

12 Jef Huysmans „Revisiting Copenhagen: Or, On the Creative Development of a Security Studies Agenda in Europe“, European Journal of International Relations, Vol. 4, No. 1, 1998, p. 492.

13 Видети: John L. Austin, ibid; Thierry Balzacq, „The Three Faces of Securitization: Political Agency, Audience and Context", European Journal of International Relations, Vol.11, No.2, 2005, 
ништа друго до илокуцијско креирање безбедности уз помоћ исказа о егзистенцијалној претњи, изреченог са намером да код публике изазове жељени перлокуцијски ефекат.

Процес секуритизације стога можемо представити као игру илокуције и перлокуције, која се у сфери безбедности манифестује кроз интеракцију секуритизујућег актера и публике. Предмет ове интеракције је секуритизујући потез уз помоћ кога секуритизатор - држава, односно политичке и сродне државоцентричне елите настоје да придобију подршку жељене публике, најчешће грађана, за примену специјалне мере приликом решавања питања које је говорним чином означено као безбедносни приоритет. Да би била успешна, секуритизација мора бити прихваћена од стране публике, тј. схваћена као оправдана и нужна. ${ }^{14}$ Сагласност публике представља жељени перлокуцијски ефекат неопходан за комплетирање секуритизујућег процеса. За његово остварење неопходно је да секуритизујући потез следи низ илокуционоконтекстуалних правила које теоретичари Копенхашке школе називају посредујућим условима (facilitating conditions) ${ }^{15}$ и који служе као својеврсна мапа пута за добијање „зеленог светла“ публике за примену специјалне мере. На првом месту говорни чин мора бити уклопљен у шаблон тзв. граматике безбедности која подразумева „конструисање заплета који укључује егзистенцијалну претњу, тачку без повратка и могући излаз“.16 Такође, он мора водити рачуна о дијалекту циљаног сектора безбедности, ${ }^{17}$ што значи да је неопходно акцентовати стожерне појмове карактеристичне за сектор који се приказује као угрожен. Граматика безбедности и безбедносни дијалект спадају у интерна правила која се тичу структуре илокуционог исказа; међутим, да би секуритизација била успешно спроведена у дело, неопходно је задовољење и два екстерна, односно контекстуална услова.

Први се односи на чињеницу да су социјални капитал и ауторитет неопходни за прихватање говорног актера као легитимног секуритизатора. Не може свако играти улогу секуритизујућег актера, нити свако ужива друштвени углед и приступ социјалним инструментима спровођења секуритизације. Због тога Бузан (Barry Buzan), Вејвер и де Вајлде (Jaap de Wilde) сматрају да је улога

p. 175; Ивана Љ. Стојановић Прелевић, Перформативи и рефлексивна комуникацијска намера (докторска дисертација), Универзитет у Београду, Београд, 2013, стр. 20-21.

${ }^{14}$ Barry Buzan, Ole Waever, Jaap de Wilde, Security: A New Framework For Analysis, Lynne Rienner publishers, Boulder/ London, 1988, p. 25.

15 Barry Buzan, Ole Waever, Jaap de Wilde, ibid, pp. 31-33.

16 Ibid, pp. 32-33.

17 Копенхашка школа негује тзв. секторски приступ феномену безбедности. Увођење сектора као јединице анализе за циљ има идентификацију и разликовање врста интеракција до којих долази између конституишућих јединица међународног система. Теоретичари ове школе разликују војни, економски, социјетални, политички и сектор животне средине. 
секуритизатора углавном резервисана за представнике државе и елите везане за центре политичког одлучивања. 18 То су превасходно политички лидери, бирократије, владе, лобисти и групе за притисак. Чак и они аутори који, попут Јухе Вуорија (Juha A. Vuori), сматрају да се листа потенцијалних секуритизатора може проширити и на нпр. опозиционе лидере, научнике или новинаре, ${ }^{19}$ признају да ови актери, без сопственог социјалног капитала, не би могли обезбедити приступ центрима одлучивања у чијим рукама се налазе они ресурси, укључујући ту и монопол силе, који су неопходни за имплементацију специјалне мере. Упркос томе, Бузан, Вејвер и де Вајлде сматрају да безбедност није искључиво домен државе, већ да она представља компетитивну арену у којој се за улогу секуритизатора може такмичити више актера. Ипак, ови аутори закључују да држава у безбедносној утакмици, услед дуге историје вршења безбедносних дужности и чињенице да је „најбоље структурирана за ту сврху“, увек има предност над другим такмичарима, те стога представља идеалног секуритизујућег актера.

Други контекстуални предуслов сугерише да секуритизујући потез има веће шансе за успех уколико садржај говорног чина реферише на објекте који су од стране публике већ доживљени као претња. Тиме се перцепција позиционира као чинилац од великог значаја за остварење жељеног перлокуцијског ефекта, док њена улога у вршењу секуритизујућег потеза остаје у другом плану.

На крају овог поглавља важно је подвући да иако секуритизујући дискурс представља један од прерогатива моћи државе, он поседује и сопствену моћ. Уколико је секуритизујући потез изведен на ваљан начин, односно уколико задовољава описане посредујуће услове, дискурс о егзистенцијалној претњи може постати креативна снага којом политичке елите уређују и преуређују друштвену, политичку и безбедносну реалност. Но уколико поменути посредујући услови нису до краја поштовани или уколико публика одбацује секуритизујући потез из неког другог разлога (нпр. услед присуства конкурентских секуритизујућих дискурса који подривају ауторитет државе), ${ }^{20}$ дискурс се може отргнути контроли

${ }^{18}$ Видети: Ole Waever, op. cit., p. 57; Barry Buzan, Ole Waever, Jaap de Wilde, op. cit., p. 35, 40.

19 Juha A. Vuori, „Illocutionary Logic and Strands of Securitization: Applying the Theory of Securitization to the Study of Non-Democratic Political Orders", European Journal of International Relations, Vol. 14, No. 1, 2008, p. 77.

${ }^{20}$ Као типичан пример компетативних секуритизујућих дискурса могли бисмо навести сукоб државе и еколошких покрета око питања загађења животне средине. Док је држава склона да овај проблем посматра из угла развоја привреде (у случају земаља у развоју, увећање индустријске производње често се представља као питање економског опстанка), покрети за заштиту животне средине овај проблем посматрају са становишта одрживог развоја и настоје да секуритизују проблем повећане емисије $\mathrm{CO}_{2}$, која се јавља као пратећи ефекат процеса индустријализације. Други, за нас релевантнији, пример конкурентског секуритизујућег дискурса јесте дискурзивно 
и окренути против званичног секуритизатора. Како то примећује Фуко „Дискурси као ни ћутања нису једном засвагда потчињени моћи или покренути против ње. Ваља уважити сложено и нестално међудејство у коме дискурс у исти мах може бити и оруђе и дејство моћи, али и препрека, камен спотицања, тачка отпора и полазиште за неку супротну стратегију. Дискурс преноси и производи моћ; он је појачава, али је и поткопава, излаже, чини ломљивом и омогућује постављање препрека пред њу“.21 У наставку рада ми ћемо поћи управо од ове потоње претпоставке, те ћемо нашу пажњу усмерити на ситуацију у којој дискурс постаје препрека успешној секуритизацији као потврди моћи државе. Реч је о ситуацији у којој секуритизатори услед интерних разлога (лоше структуриран секуритизујући чин) и екстерних услова (нагла експанзије дигиталне масовне самокомуникације путем интернета) губе контролу над секуритизујућим дискурсом. Под таквим околностима и сам дискурс мења своја својства, губи унутрашње и спољашње редукционе механизме и постаје пропустљив за све већи број „неконвенционалних“ претендената на улогу секуритизатора. Над оваквим дискурсом секуритизатори више немају контролу, и он не само да не постиже жељени перлокуцијски ефекат већ, напротив, изазива и појачава одијум код публике. Поменути феномен ми ћемо назвати илокуциона какофонија и према нашој тврдњи он представља кључ за разумевање потенцијалног (у дугорочној перспективи сагледаног) неуспеха секуритизације актуелне пандемије.

\section{ПРИНЦИП ЗГРУШАВАЊА ДИСКУРСА И ИЛОКУЦИОНА КАКОФОНИЈА}

На основу свега што је речено у претходном поглављу можемо закључити да је секуритизација вертикални процес који подразумева једносмерну комуникацију владајућих елита и грађана. У таквој комуникацији политичке елите располажу институционалним ауторитетом и социјалним капиталом на основу којих јавност државу перципира као легитимног секуритизатора. Поменути институционални ауторитет и социјални капитал омогућују елитама не само ексклузивитет монопола силе, који је неопходан да пружи гаранцију поштовања специјалне мере, већ и отворени приступ разгранатој мрежи штампаних, електронских и дигиталних комуникационих ресурса (новине, радио, телевизија и интернет портали), путем којих се секуритизујућа порука презентује. Отуда Копенхашка школа исправно закључује да је држава повлашћени секуритизатор, с обзиром на чињеницу да mainstream медији за друге потенцијалне секуритизујуће актере остају само делимично отворени (у зависности од њиховог сопственог социјалног

деловање антиваксерског покрета, које за циљ има да поткопа поверење грађана у здравствени монопол државе. Но о овом примеру ће више речи бити у наставку рада.

21 Мишел Фуко, Историја сексуалности, према Сара Милс, ор. сit., стр. 50. 
капитала), а да институционални apparatus силе у потпуности остаје изван њиховог домашаја. Дакле, како то примећују Бузан, Вејвер и де Вајлде, структурна организација државе олакшава задовољење поменутих посредујућих услова, нарочито сам чин изговарања/обзнањивања претње (поседује механизме који гарантују да ће се безбедносни исказ „чути“), као и њено легитимисање (захваљујући општеприхваћеном друштвеном ауторитету). Међутим, када је реч о губитку контроле над секуритизујућим дискурсом, ово питање се тек делимично тиче задовољења посредујућих услова успешности, а знатно више питања отворености, односно пропусности безбедносног дискурса за алтернативне актере - оне који долазе изван круга државоцентричних елита.

Према Фукоовом концепту дискурзивног поретка, 22 специјализовани дискурси, какав је и безбедносни, нису доступни свима. Наиме, поредак дискурса поседује сопствена правила селекције и регулације пропустљивости. Фуко истиче како се у сваком друштву „продукција дискурса у исти мах контролише, селектује, организује и расподељује, и то извесним поступцима чија је улога да укроте моћ и опасности дискурса, да овладају његовим непредвидљивим догађајима, да избегну његову тешку и опасну материјалност“.23 Ова правила проређивања (raréfaction) Фуко дели на поступке екстерне контроле (принципи искључивања, поделе и одбацивања и супротстављања истинитог и лажног) и интерне контроле (принципи коментара, аутора, дисциплине и проређивања говорног субјекта). Међутим, треба имати на уму да је овај теоријски модел развијен у периоду доминације штампаних и електронских медија и да је првенствено усмерен на објашњење Zeitgeista, који је претходио узлету дигиталних технологија. Као такав Фукоов модел више гледа у прошлост него што настоји да антиципира предстојеће промене у обрасцима комуникације. Радио и телевизија могли су тек магловито наговестити силовитост дигиталне револуције која ће довести до експанзије тзв. друштвених медија и мрежа и настанка новог вида комуникације који је Мануел Кастелс окарактерисао као масовно самокомуницирање (mass selfcommunication). ${ }^{24}$ У судару са овом појавом традиционални механизми контроле дискурса, који су важили вековима, губе на својој учинковитости, што за последицу има повећану пропустљивост специјализованих дискурса, укључујући и безбедносни. Ми ћемо се у наставку поглавља фокусирати на један од поменутих Фукоових механизама - принцип проређивања говорног субјекта, за који сматрамо да је од пресудног значаја за разумевање феномена илокуционе какофоније. Овај принцип почива на идеји да „нису све области дискурса једнако отворене и приступачне; неке од њих су у великој мери брањене (оне су разликоване и разликују се), док друге изгледа да су изложене сваком ветру и да

\footnotetext{
22 Мишел Фуко, Поредак дискурса, Карпос, Лозница, 2019.

${ }^{23}$ Мишел Фуко, Ibid, стр. 9.

${ }^{24}$ Мануел Кастелс, Мреже револта и наде: Друштвени покрети у доба интернета, Службени гласник, Београд, 2018, стр. 25.
} 
се без претходних ограничења стављају на располагање сваком говорном субјекту“.25 Свако друштво успоставља услове примене дискурса и одређује известан број правила везан за одређене области дискурса, тј. специјализоване дискурсе. Тако се успоставља дискурзивни поредак у који не може ући нико ко не „задовољи извесне захтеве или ако није од почетка квалификован за то“.26 Другим речима, поље специјализованих дискурса је ексклузивно, и у њега се може ући само уколико за то постоје неопходне квалификације. Свака дискурзивна област има своје критеријуме. Тако нпр. књижевни дискурс претпоставља књижевну етаблираност учесника у виду статуса књижевника или критичара, док здравствени дискурс од својих носилаца захтева образовање из области медицине. Да би одређени говорни актер био јавно прихваћен као легитиман носилац или гласноговорник одређеног дискурса, у нашем случају здравственог и безбедносног он мора поштовати задати сет правила.

Међутим, ова правила важила су у поретку дискурса који данас слободно можемо означити као „традиционалан“. Но, наглом експанзијом дигиталних технологија и увођењем масовне самокомуникације у дискурзивну једначину принцип проређивања говорног субјекта, чији је главни задатак био очување ексклузивитета специјализованих дискурса, готово да је у потпуности поништен. Захваљујући комуникацији путем интернета и феномену online виралности, тј. садржајима који се великом брзином „шире“ интернетом, дељењем (share) на друштвеним медијима и мрежама, грађани - умрежени појединци, некадашња нема публика дискурзивних елита, сада су у могућности да за себе присвоје одређене атрибуте носилаца специјализованих дискурса, упркос чињеници да не задовољавају улазне критеријуме које пред њих поставља принцип проређивања говорног субјекта. Овакав заокрет унутар поретка дискурса могућ је захваљујући фундаменталној промени у сфери комуницирања оличеној у масовној самокомуникацији коју Кастелс одређује као употребу „интернета и бежичних мрежа као платформи за дигиталну комуникацију“.27 Оваква, наизглед једноставна дефиниција, у себи садржи сложен образац који истовремено наглашава два важна комуникациона аспекта - масовност и ауто-комуникацију. С једне стране у питању је масовно комуницирање, јер „обрађује поруке многих ка многима, може да допре до мноштва прималаца и да се повеже са бескрајним мрежама које преносе дигитализоване информације, како у локалу тако и широм света“;28 с друге стране, овај феномен има карактеристике самокомуникације, „јер пошиљалац аутономно одлучује о производњи порука, аутономно доноси одлуку о примаоцу поруке и преузимању поруке с комуникационих мрежа“.29 Важно је

\footnotetext{
25 Мишел Фуко, ор. cit., стр. 24.

26 Ibid, стр. 24.

27 Мануел Кастелс, оp. cit., стр. 25.

${ }_{28}$ Мануел Кастелс, Ibid, стр. 25.

${ }^{29}$ Ibid.
} 
истаћи да у основи масовног самокомуницирања леже хоризонталне мреже комуникације, над којима је тешко успоставити вертикалну контролу, и које, захваљујући својој технолошкој платформи, чине могућим „да неки друштвени актер, појединачни или колективни, изгради своју аутономију у односу на институције друштва“.30 На тај начин пошиљалац поруке и њен реципијент остају изван домашаја контроле елита (политичких и стручних) и њихових дискурзивних правила, а главна карактеристика овог новог вида комуникације јесте потпуна самосталност приликом одабира циљане публике и избора између мноштва порука у виртуелном простору. Тиме се у виртуелном свету дигиталних технологија зидови који омеђују специјализоване дискурсе постепено урушавају, стварајући отворени дискурзивни простор који је испуњен све већим бројем говорних актера неспутаних захтеваним компетенцијама, али зато опремљених технолошким средствима која омогућују пенетрацију у жељени дискурс. У којој је мери интернет постао релевантан комуникацијски, тј. самокомуникацијски медиј, а самим тиме и социјални оквир подесан за креирање, преношење и усвајање различитих дискурса, говори нам податак да је друштвена мрежа Фејсбук (Facebook) још 2015. године од 1.39 милијарди корисника, премашила укупан број становника најмногољудније земље света - Кине. ${ }^{31}$

Виртуелно пространство интернета није само место сусрета и саобраћања његових корисника, већ да је у питању глобални дигитални стожер знања и информација из различитих временских епоха и крајева света, доступног на „клик“ свакоме ко има технолошке могућности да приступи мрежи. Но треба имати на уму да упркос томе што интернет „омогућава отворен приступ вишемање свим информацијама и знању које је људска врста произвела у новије време, то знање се дистрибуира у систему, тј. оно је само потенцијално знање групе. Сходно томе, све већи отворени приступ информацијама на мрежи не чини нас мудријим као друштво. Он нас чини само потенцијално мудријим“.32 Интернет је појединцима олакшао приступ непрегледном фундусу знања, укључујући ту и стручно и научно знање, но он нипошто не представља гаранцију да ће то знање бити прихваћено и обрађено на прави начин. Другим речима - доступност знања и информација не значи аутоматски и њихово правилно разумевање и усвајање. Тако је нпр. „медицинско знање, које је некада било на располагању ексклузивно медицинским стручњацима, сада постало доступно свима и може бити дељено у постовима који постају 'вирални'“.33 Но, ово знање често бива погрешно интерпретирано, па чак и намерно дезинтерпретирано и злоупотребљено од

\footnotetext{
30 Ibid.

31 Vincent F. Hendricks, Pelle G. Hansen, Infostorms: Why do we 'like'? Explaining individual behavior on the social net, Spinger, Cham, 2016, p. 36.

32 Vincent F. Hendricks, Pelle G. Hansen, ibid, pp. 36-37.

33 Olivia Benecke, Sarah Elizabeth DeYoung, „Anti-Vaccine Decision-Making and Measles Resurgence in the United States“, Global Pediatric Health, Vol. 6, 2019, pp. 1-5.
} 
стране тзв. антиваксерског покрета. Борци против вакцинације своју „аргументацију“ најчешће граде управо на дезинтерпретацијама и надоградњама званичних података глобалне здравствене заједнице, коју потом посредством друштвених медија и мрежа пласирају публици као неупитне медицинске „истине“. На тај начин аутсајдери улазе у поље специјализованог дискурса - у овом случају здравственог, уносећи пометњу и подривајући ауторитет његових традиционалних носилаца - лекара, научника и других здравствених радника. Хендрикс (Vincent F. Hendricks) и Хансен (Pelle G. Hansen) примећују да када је у питању „постављање података у јавном простору интернета, капије истине углавном нико не чува [...] То значи да знање које је доступно online није само дистрибуирано, већ је и затрпано испод наслага буке различитих интереса и небитних информација“.34 Тако напослетку долазимо управо до феномена који ћемо ми назвати илокуционом какофонијом, а који би у сфери безбедности могао бити означен и као секуритизујућа какофонија.

У претходним пасусима објаснили смо појаву/принцип коју бисмо могли означити као згрушавање говорног субјекта или једноставније као згрушавање дискурса. Реч је о својеврсном епифеномену процеса масовне самокомуникације, који подразумева ситуацију у којој специјализовани дискурс уместо да буде „проређен“ и препуштен само одабранима, постаје „пренасељен“ и незаштићен, односно лишен регулативних и саморегулативних механизама. Увећавање броја носилаца дискурса за собом повлачи и његову атомизацију - могућност појаве супротстављених и компететивних наратива, што за последицу има појаву дисхармоничног вишегласја - илокуционе какофоније. Илокуциону какофонију стога можемо дефинисати као присуство мноштва несинхроних гласова који „заглушују“ и „делегитимишу“ традиционалне, тј. легитимне носиоце дискурса. У сфери здравства и безбедности илокуциона какофонија могла би бити одређена као плуралитет неусаглашених (псеудо)стручних и секуритизујућих гласова усмерених ка делегитимизацији званичних ауторитета, превасходно стручњачких елита и носилаца власти у улози легитимних провајдера безбедности. У случају секуритизације неповерење у државу као секуритизујућег актера неретко поприма димензију отвореног антагонизма, при чему се политичке елите најчешће перципирају као део безбедносне претње, а понекад и као сама претња.

Будући да илокуциона какофонија за последицу има детронизацију стручњачких елита са пиједестала арбитара истине, њени ефекти не могу бити ограничени искључиво на виртуални простор друштвених медија и мрежа. Подривањем поверења у владајуће елите они се нужно преливају и у реални, материјални свет, чиме постају нови друштвени фактор који утиче на социјалнополитичка дешавања и њихову динамику. У наредном поглављу пример јавног одијума и отпора грађана Србије секуритизујућим мерама намењених сузбијању вируса

\footnotetext{
${ }^{34}$ Vincent F. Hendricks, Pelle G. Hansen, op.cit., p. 37
} 
ковид 19, до кога је дошло по окончању првог пандемијског таласа и укидања ванредног стања уведеног након проглашења глобалне пандемије, биће искоришћен као студија случаја за проучавање услова настанка и социјалнополитичких ефеката илокуционе какофоније.

\section{ВИРАЛНИ ОТПОР ВАНРЕДНИМ МЕРАМА СУЗБИЈАЊА ПАНДЕМИЈЕ КОВИДА 19 У РЕПУБЛИЦИ СРБИЈИ}

Последње поглавље овог кратког екскурса усмерено је на проблем изостанка жељеног односа илокуције и перлокуције у процесу секуритизације пандемије ковида 19 у Републици Србији. Одијум дела јавности према социјално рестриктивним мерама усмереним на превенцију и сузбијање пандемије ковида 19 , до кога је дошло након укидања ванредног стања уведеног у марту 2020, тумачићемо лоше структурираним секуритизујућим потезом, који није у потпуности задовољио захтеве посредујућих услова секуритизације. Наиме, говорни чин указивања на егзистенцијалну претњу препуштен је већем броју стручних лица, што из домена здравства, што из домена политике, који су, како је криза одмицала, све чешће давали нејасне, контрадикторне и међусобно супротстављене изјаве, што је допринело наглом паду поверења у стручњачке елите (тзв. Кризни штаб) и све гласнијем отпору дела грађанства напорима државе да ванредним мерама настави борбу против заразе. Илокуциона какофонија која је на тај начин створена ескалирала је грађанским протестима, који су након неколико дана уличних немира и оштрих сукоба грађана и полиције одвратили власти од даљег заоштравања социјалнорестриктивних мера сузбијања пандемије.

Током првих месеци пандемијске кризе, а нарочито у периоду непосредно пре проглашења светске пандемије и увођења ванредног стања у Републици Србији, ${ }^{35}$ однос државних званичника према пандемији поставио је дискурзивни темељ за појаву илокуционе какофоније која ће на дуже стазе нанети велику штету секуритизујућим напорима државе. На овом месту важно је уочити како дискурс о зарази испрва уопште није поседовао секуритизујућу компоненту, већ да је напротив био усмерен ка „релаксацији“ ситуације и умањењу претње. Тако су се нпр. на конференцији за штампу одржаној у Председништву Републике Србије 26. фебруара 2020. могле чути констатације да је реч о „најсмешнијем вирусу на свету“ и болести „много слабијој од грипа“, те да је једина компликација коју

35 у Републици Србији је 15. марта 2020. због појаве и опасности од убрзаног ширења вируса ковида 19 у Републици Србији уведено ванредно стање. Након два дана уведена је и мера полицијског часа, а недуго потом проглашена је и епидемија од већег епидемиолошког значаја. 
ковид 19 може изазвати упала плућа. ${ }^{36}$ Другим речима: „Са места које је перципирано као високо кредибилно, домаћој јавности тада су упућене поруке које је уверавају у безазленост и инфериорност вируса 'ковид 19““.37 На овај начин представници државних власти и медицинске струке покушали су релативизују здравствене ризике које са собом носи пандемија и да зауздају панику која се убрзано ширила међу грађанима Србије. Овакав дискурс пропраћен је и снажном кампањом таблоидних медија који су сензационалистичким текстовима настојали да дискредитују Светску здравствену организацију (World Health Organization) и да вирус прогласе „преваром века“.38 Међутим, недуго потом, политички врх и медицински стручњачки тим су начинили потпуни дискурзивни заокрет, пласирајући секуритизујући наратив усмерен ка апострофирању озбиљности претње и нужности предузимања ванредних мера у циљу превенције и сузбијања заразе. Тиме је у размаку од само петнаестак дана наратив државних званичника од потпуне негације претње претворен у „звоно на узбуну“, чиме је дискурс о пандемији крајње невешто и нимало суптилно гурнут у другу крајност. Последица оваквог обрта била је нагли пад поверења у државу и кризни штаб,39 нарочито изражен у периоду током друге половине трајања ванредног стања и непосредно по његовом окончању. Ово неповерење додатно је продубљивано с једне стране бројним недоследностима и међусобно противречним изјавама чланова Кризног штаба, док је са друге стране његовом расту погодовало згрушавање дискурса на друштвеним медијима и мрежама, тј. све већи број алтернативних претендената на место секуритизатора, који су секуритизујући фокус изместили са вируса на државу, означавајући управо структуре власти (политички врх и стручњачке елите) као извор егзистенцијалне претње.

Непосредно након избијања светске пандемије, а нарочито након њеног званичног проглашења од стране Светске здравствене организације, друштвени медији и мреже бележе интензивирање антиваксерског дискурса. Бројни истакнути борци против вакцина, попут психијатрице др Јоване Стојковић, лекарке и посланице, проф. др Наде Костић или драматуршкиње Маје Волк, видели су у развоју ситуације шансу за промоцију сопствених тумачења актуелне ситуације и прилику за мобилизацију шире подршке у борби против вакцина, укључујући ту и још увек непостојећу вакцину против ковида 19. На Јутјуб (YouTube) каналу који води др Стојковић током трајања ванредног стања, као и након његовог окончања, учестало су постављани видео-клипови у којима ова

\footnotetext{
36 Ирина Милутиновић, „Информациона политика у време пандемије вируса 'Ковид 19' у Србији“, Политичка ревија, Vol. 64, No. 2, 2020, стр. 249.

${ }^{37}$ Ирина Милутиновић, Ibid, стр. 249.

38 Ibid, стр. 250.

39 „Грађани Србије немају поверење у званичне информације у вези са корона вирусом“, Valicon, 06. јул 2020, https://www.valicon.net/2020/07/gradani-srbije-nemaju-poverenje-uzvanicne-informacije-u-vezi-sa-korona-virusom/, 9/11/2020.
} 
антиваксерска лидерка позива грађане на отпор мерама које је увео Кризни штаб. У овим видео-клиповима, као и у објавама на њеним Фејсбук страницама, вирус ковид 19 представљен је као део глобалне завере усмерене ка потчињавању светског становништва од стране скривених, завереничких центара моћи. Тако нпр. др Стојковић у видео-обраћању из априла 2020. постојећу пандемију назива „паникдемијом“, за коју је одговоран главни креатор светског јавног здравља Бил Гејтс (Bill Gates).40 Илустрације ради, ваља навести и конференцију за штампу одржану 29. априла 2020, у холу Народне скупштине Републике Србије, на којој је проф. др Нада Костић изнела низ сензационалистичких и неутемељених тврдњи. Ова самостална народна посланица је том приликом изјавила да је пандемија покриће за глобалну инсталацију 5Г мреже, те да повећани морталитет код овог обољења није последица вируса, већ да је прави кривац 5Г мрежа која оболелима одузима кисеоник. Баш као и у случају др Стојковића, и овде се за пандемију криве моћници из сенке - Бил Гејтс и Џорџ Сорош (George Soros).41 Поред ових појединаца, који међу српским борцима против вакцина уживају статус својеврсних антиваксерских икона, у виртуелном свету друштвених мрежа присутне су и бројне странице и групе које окупљају њихове истомишљенике. Тако се на пример на Фејсбуку могу наћи следеће групе: „Вакцинација и слобода избора/Vaccine Freedom of Choice“, „Стоп обавезној вакцинацији у Србији“, „Право на природну имунизацију и необавезно шприцање имунопрепаратима“ и „Стоп присилној корона-вакцинацији и глобализацији“.42 Након избијања пандемије ковида 19 ове странице су стављене у службу дискурса који пропагира грађански отпор здравственим мерама и мерама социјалне рестрикције које пропагира Кризни штаб, а садржаји који њима доминирају и које путем post-ова (објава), share-ова (дељења) и like-ова (свиђања) креирају, шире и промовишу њихови чланови - може бити окарактерисан као наратив о глобалној завери, најчешће довођеној у везу са Билом Гејтсом и 5Г мрежом.

Треба имати на уму да број грађана активно (путем post-ова и share-ова) или пасивно (путем like-ова) укључених у антиваксерски online дискурс није занемарљив, као и да њихове објаве због сензационалистичког или секуритизујућег карактера врло брзо постају виралне и лако уочљиве од стране публике на мрежи. Тако нпр. Јутјуб страница др Јоване Стојковић има више од 16.000 пратилаца (subscriber-a), њен Фејсбук профил има 26.896 like-ова и 29.668 follower-a (пратилаца), док званична страница њеног покрета Живим за Србију на

\footnotetext{
40 „Ваистину вакциНАЦИја“, Үоutube - Покрет живим за Србију др Јована Стојковић, 12. април 2020, https://www.youtube.com/watch?v=simzoI_fL74 /6/10/2020/

41 „Скупштина - ово се крије од народа: Докторка Костић открила праву истину о вирусу“, Youtube - СРБИН.инфо, 01. мај 2020, https://www.youtube.com/watch?v=8LtEAjXKv5U\&ab_channel=\%D0\%A1\%D0\%A0\%D0\%91 \%D0\%98\%D0\%9D.\%D0\%B8\%D0\%BD\%D1\%84\%D0\%BE, 6/10/2020.

42 Наведене су само групе које броје више од 1000 чланова.
} 
истој друштвеној мрежи бележи 4117 like-а и 4310 follower-a. ${ }^{43}$ С друге стране, ни поменуте деперсонализоване Фејсбук групе нису ништа мање бројне - странице „Стоп обавезној вакцинацији у Србији“ и „Стоп присилној КОРОНА-вакцинацији и глобализацији“ окупљају по 8.800 чланова; група „Вакцинација и слобода избора/Vaccine Freedom of Choice“ броји 5.682 чланова, док група „Право на природну имунизацију и необавезно шприцање имунопрепаратима“ бележи нешто скромнији број од 1.300 чланова. ${ }^{44}$

Контрадикторност у изјавама Кризног штаба, званичног секуритизатора, који се у име државе обраћао током трајања ванредног стања, као и описана појачана активност истакнутих антиваксера и њихових следбеника, довела је до стварања илокуционе какофоније, која је у ситуацији актуелне пандемије попримила облик секуритизујуће буке која је заглушила званичне захтеве државе за поштовањем ванредних мера. Коначни исход овакве ситуације био је ескалација грађанског незадовољства до које је дошло 7. јула 2020, неколико сати након окончања конференције за штампу посвећене наглом поновном расту броја заражених од вируса, на којој је председник Републике Србије Александар Вучић најавио реактивирање мера социјалних рестрикција које су биле на снази током трајања ванредног стања - забране окупљања више од пет особа на јавним местима и увођење забране кретања током послеподневних/вечерњих сати и викенда. Протести су започели у Београду, да би се наредних дана проширили и на друге градове у Србији - Нови Сад, Ниш, Зрењанин и Крагујевац. На демонстрацијама је учествовало неколико хиљада грађана, а већ током првог дана дошло је до оштрих сукоба демонстраната и полиције. Након неколико дана грађанских немира политички врх је одустао од увођења планираних мера и ситуација на улицама Београда и других градова у Србији се постепено вратила у нормалу.

Због чега је након успешног увођења ванредних мера и ванредног стања дошло до неуспеха поновљеног покушаја секуритизације пандемије? Како смо већ истакли, први део кривице сносе државни секуритизатори, који су од самог почетка кризе на погрешан начин реализовали секуритизујући потез. Наиме, српске политичке и стручњачке елите су непосредно пре избијања пандемије начиниле озбиљне пропусте приликом извођења секуритизујућег потеза, да би током иницијалне фазе борбе против пандемије наставиле у истом маниру, делајући потпуно мимо захтева посредујућих услова успешне секуритизације. Пре свега, званични секуритизујући дискурс није успео да испоштује тзв. граматику безбедности, тј. није био довољно успешан да грађане на дуже стазе убеди да ковид 19 представља егзистенцијалну претњу по читаво друштво. Такође, њиме публици није понуђен уверљив план акције сузбијања пандемије, чиме је пропуштена прилика да се одмах по увођењу ванредних мера осигура њихово дугорочно поштовање неопходно за што успешнију борбу против вируса. С друге стране,

\footnotetext{
43 Прегледано 6/10/2020.

44 Прегледано 6/10/2020.
} 
користећи поменуте пропусте легитимних секуритизатора, српски антивакциони покрет допринео је стварању илокуционе, тј. секуритизујуће какофоније, чиме је подрио званичне здравствене ауторитете и код немалог дела грађана пробудио сумњу у праве намере политичких елита.

\section{ЗАКЉУЧАК}

Искуство Републике Србије и грађански отпор ванредним противпандемијским мерама никако није усамљен случај. У тренутку писања ових редова, европске престонице попут Берлина и Лондона потресају грађанске демонстрације, које су организовале различите друштвене групе уједињене у противљењу новим владиним антиковидним рестрикцијама. Међу њима предњаче тзв. коронаскептици (corona sceptics), антимаскери (anti-maskers), антиваксери, борци против 5Г мреже и други теоретичари завере. Сви они претендују на улогу новог секуритизатора, и у тој дискурзивној борби измештају фокус грађана са пандемије и вируса на политичке елите као (праву) претњу.

Ми смо у раду покушали да расветлимо кључне предуслове који овим дојучерашњим дискурзивним аутсајдерима широм отварају врата специјализованих дискурса - безбедносног и здравственог, допуштајући им притом да мењају правила игре и положе „право“ да као истински vox populi преузму „жезло“ и прерогативе секуритизације. Ова транзиција одвија се махом у виртуелном свету дигиталних технологија, у коме је продукција вести и мишљења постала „хидра са много глава (за сваке новине које умру рађа се 2000 нових блогова, Фејсбук и Твитер feed-ова!).45 У том свету, загушеном великим бројем говорних субјеката, испуњеном буком илокуционог вишегласја и контрадикторношћу исказаних порука, традиционални секуритизујући ауторитет државних и стручњачких елита бива свргнут са трона и доживљава сопствени сумрак, чиме, последично, слаби и његова способност да контролише дешавања у реалном окружењу. Тиме се, без обзира на описане (наизглед неумитне) промене унутар поретка дискурса, као неупитна истина намеће чувена Фукоова опсервација о томе како нас историја учи да „дискурс није просто оно што борбе или системе доминације преводи у језик, него је он оно за шта се и чиме се бори. Дискурс је моћ коју треба задобити“.46 Управо у овој примедби лежи рецепт за успешну борбу против актуелне пандемије. Рестриктивне здравствене и социјалне мере, лекови и вакцина, само су завршни ударац у бици која тек предстоји. Реч је о борби која ће отпочети управо речју, а чија ће награда бити повратак поретка дискурса његовим легитимним господарима. Наравно, под

\footnotetext{
45 Jayson Harsin, "Regimes of Posttruth, Postpolitics, and Attention Economies", Communication, Culture \& Critique, Vol. 8, No. 2, 2015, p. 329.

${ }^{46}$ Мишел Фуко, op. cit., стр. 9-10.
} 
условом да су исти спремни да уче на својим грешкама. У супротном, да парафразирамо Фукоа, дискурс може постати моћ која ће нас докрајчити.

\section{ЛИТЕРАТУРА}

- „Ваистину вакциНАЦИја“, Youtube - Покрет живим за Србију др Јована Стојковић, 12. април 2020, https://www.youtube.com/watch?v=simzoI_fL74.

- „Грађани Србије немају поверење у званичне информације у вези са корона вирусом“, Valicon, 6. јул 2020, https://www.valicon.net/2020/07/gradani-srbijenemaju-poverenje-u-zvanicne-informacije-u-vezi-sa-korona-virusom/.

- „Скупштина - ово се крије од народа: Докторка Костић открила праву истину о вирусу“, Youtube - $\quad$ СРБИН.инфо, $1 . \quad$ мај 2020, https://www.youtube.com/watch?v=8LtEAjXKv5U\&ab_channel=\%D0\%A1\%D0\%A0 \%D0\%91\%D0\%98\%D0\%9D.\%D0\%B8\%D0\%BD\%D1\%84\%D0\%BE.

- Austin, John L. How to Do Things With Words, Oxford University Press, London, 1962.

- Benecke, Olivia and DeYoung, Sarah Elizabeth. „Anti-Vaccine Decision-Making and Measles Resurgence in the United States“, Global Pediatric Health, Vol. 6, 2019, pp. $1-5$.

- Buzan, Barry, Waever, Ole, Wilde, Jaap de. Security: A New Framework For Analysis, Lynne Rienner publishers, Boulder/ London, 1988.

- Fairclough, Isabela and Fairclough, Norman. Political Discourse Analysis: A method for advanced students, Routledge, London/New York, 2012.

- Hendricks, Vincent F., and Hansen, Pelle G. Infostorms: Why do we 'like'? Explaining individual behavior on the social net, Spinger, Cham, 2016.

- Huysmans, Jef. „Revisiting Copenhagen: Or, On the Creative Development of a Security Studies Agenda in Europe“, European Journal of International Relations, Vol. 4, No. 1, 1998, pp. 479-505.

- Jayson Harsin, "Regimes of Posttruth, Postpolitics, and Attention Economies", Communication, Culture \& Critique, Vol. 8, No. 2, 2015, p. 327-333.

- Thierry Balzacq, „The Three Faces of Securitization: Political Agency, Audience and Context", European Journal of International Relations, Vol.11, No.2, 2005, pp. 171-201.

- Vuori, Juha A. „Illocutionary Logic and Strands of Securitization: Applying the Theory of Securitization to the Study of Non-Democratic Political Orders“, European Journal of International Relations, Vol. 14, No. 1, 2008, pp. 65-99.

- Waever, Ole. „Securitisation and Desecuritisation“, in Ronnie D. Lipschutz (ed.), On security, Columbia University Press, New York, 1995.

- Кастелс, Мануел, Мреже револта и наде: Друштвени покрети у доба интернета, Службени гласник, Београд, 2018.

- Милс, Сара. „Шта је дискурс?“, У: Мишел Фуко, Поредак дискурса, Карпос, Лозница, 2019. 
- Милутиновић Ирина, „Информациона политика у време пандемије вируса 'ковид 19' у Србији“, Политичка ревија, Vol. 64, No. 2, 2020, стр. 243-263.

- Стојановић Прелевић, Ивана Љ. Перформативи и рефлексивна комуникацијска намера (докторска дисертација), Универзитет у Београду, Београд, 2013.

- Фуко, Мишел. Археологија знања, Плато, Издавачка књижница Зорана Стојановића, Београд/Нови Сад, 1988.

- Фуко Мишел, Поредак дискурса, Карпос, Лозница, 2019.

- Хол Стјуарт, Запад и остатак света: Дискурс и моћ, Карпос, Лозница, 2019.

\title{
SECURITIZATION (IN THE TIME) OF THE PANDEMIC: ILLOCUTIONARY CACOPHONY AND VIRAL RESISTANCE TO COVID 19 EMERGENCY MEASURES IN THE REPUBLIC OF SERBIA
}

\begin{abstract}
Author deals with the issue of securitization of the COVID-19 pandemic in the Republic of Serbia, by focusing attention on the discourse of resistance to emergency measures which emerged among the part of the citizens immediately after their introduction. This discourse is primarily present in the online community and, thanks to its viral nature, has spread very quickly on social media and networks. The call to oppose introduced anti-pandemic measures has the effect of weakening the efficiency of the state as a securitizing actor and reduction of the support for the security policy of long-term implementation of social restrictions intended to combat the infection. The aim of the paper is to point out, through a theoretical elaboration of the official securitizing discourse and the discourse of its opponents, the reasons that led to the loss of trust of the general public in the authority of political and experts elites as legitimate combatants against the virus. The author's main thesis is that today arena of health security has several contenders for the role of securitizing actor, which indicates a change in the valid rules of specialized discursive order, primarily those concerning their control and self-regulation. To support this thesis, the author introduces two innovative theoretical concepts into the traditional pattern of securitization - the principle of coagulation of discourse and illocutionary cacophony.
\end{abstract}

Keywords: COVID-19, discourse, securitization, securitizing actor, coagulation of discourse, illocutionary cacophony, emergency measures, social network, resistance to emergency measures, anti-vaccine movement 